\title{
Prognostication of the asymmetry of population incomes in Ukrainian regions
}

\author{
Kostenko Anna*; Danyluk Liudmyla
}

Institute of Economic and Legal Studies, National Academy of Sciences, Ukraine

To whom correspondence should be addressed.Email:vasilchuk_80@ukr.net

\begin{tabular}{|l|l|l|l|l|}
\hline DOI: & Received: & Revised: & Accepted: & Published: \\
$10.22437 /$ ppd.v9i5.15260 & 22.10 .2021 & 21.11 .2021 & 02.12 .2021 & 31.12 .2021 \\
\hline
\end{tabular}

\begin{abstract}
The article presents the results of the medium-term forecast of income asymmetry of the population of Ukraine. Of the set of special research methods, statistical analysis was used. The initial information for the forecast was the official statistical data, namely: the income of the population of Ukraine in the dynamics by the type of economic activity and in the regional section over the past ten years. Construction of the forecast of the income and the definition of asymmetry was carried out based on the generalization of homogeneous phenomenons (million UAH and ten years). The average values were used to compare the obtained results, summarizing the characteristics of mass, qualitatively homogeneous socio-economic phenomenons, which scientifically predicted the main prospects. The results show a steady trend in the asymmetry of income asymmetry in Ukraine (both by type of economic activity and region), which will remain until 2024. In addition, it is found that Luhansk and Donetsk regions and the indicator (property income received) require additional research by surveying to establish the key risk factors.
\end{abstract}

Keywords: Income asymmetry, Inequality, Poverty, Prognostication

JEL Classification: C53, J31, R13

\section{INTRODUCTION}

In the modern world, such a social phenomenon as the asymmetry of the population's income is presented as a multidimensional interaction process and mutual influence of various factors. In Ukrainian society, the factors of increasing the asymmetry of incomes of the population can be attributed to the protracted socioeconomic crisis over the past thirty years. Another factor causing the increase in population income asymmetry is a large sector of the underground economy and the labor market situation (which is characterized by high unemployment, low wages, and labor productivity).

A low level of public health is a consequence of the low incomes of a significant part of the population. The main features of which can be considered the average life expectancy at birth, a high level of child death and death at working age, disability, the attitude of the population to the prevention and treatment of diseases, as well as the possibility of purchasing paid medical services, etc., In these conditions, the adoption of informed management decisions regarding the processes of reproduction of the vital 
activity of society in the presence of a deepening socio-economic differentiation of the population. It becomes important to scientific research that presupposes the scientific validity of modern trends based on diagnostics prevailing in each area of the territory's life, scripts of future development, taking into account the assessment of possible results of the taken decisions - both positive and negative.

For many years, the problems of forecasting the main parameters of the population's income have attracted the attention of government, business structures, and scientists. The works of scientists from different countries and periods have highlighted various theoretical, methodological, and practical aspects related to the income asymmetry of the population. In particular, the fundamental aspects of poverty, wealth, and income inequality are reflected by representatives of classical, neoclassical political economy, including Kene, Marx, Malthus, Mill, Ricardo, Smith. Marshall, Pi, Clark, Pareto, Engel, and others. So in the works of Quesnay, who is the author of the theory of net income from land and the founder of the economic term "reproduction", attempts were made to divide society into classes by distinguishing three groups of agents in the public economy (Quesnay, 1960). Marx later criticized Quesnay's theory. He rejected the axiomatics of the table, declaring the theory of "pure product" false and the concept of dividing society into three classes - incorrect.

According to Malthus (1836), "the population is growing exponentially, and the means of subsistence - in arithmetic" gives rise to an imbalance in the welfare of various segments of the population, that is, asymmetry. This statement could be true nowadays, except for one thing. Malthus, in his researches, used incorrect, by today's standards, migration statistics (does not take into account emigrants), did not take into account the mechanisms of self-regulation of the population size, leading to the demographic transition. In addition, it should be noted that during the time of Malthus, a clear asymmetry in income was observed only in large cities, while now this phenomenon has covered entire continents (including all developed countries without exception)

Follower Ricardo, within the framework of his research "on freedom", Mill touched upon the problems of income formation and the possibility of the development of society, focusing on the aspects of private property. He believed that property relations form the directions and proportions of the income distribution. The best state of humanity would be when "no one is poor, no one wants to become richer, and there is no reason to fear being thrown back because of the efforts of others to push forward." (Mill, 1993). The key conclusions of Mill are relevant at present. However, the existing realities indicate the presence of inequality, one of which is an asymmetry in incomes. This problem does not disappear but only transforms, acquiring different colors and manifestations.

Ricardo's ideas had a tremendous influence on the subsequent development of economic theory, including developments in income distribution. In particular, Ricardo's labor theory of value, according to which "there are three main social classes and the corresponding three types of income" (Ricardo, 1852), was applied by socialists, including Marx, to substantiate the redistribution of wealth. However, some severely criticized the methodological aspects of Ricardo. So, Schumpeter, the application of the results obtained based on the methodology proposed by Ricardo to the solution of practical problems called "Ricardian sin", argues that "this is an excellent theory that can never be refuted - it has everything except meaning" (Schumpeter, 2004). 
The founder of the modern theory of poverty, in the opinion of the overwhelming majority of economists, is Smith, who is the main source of "wealth" called "economic development - the forces and laws operating in human society, thanks to which the total income grows, it is also fairly distributed" (Smith, 2016).

Income inequality, the theory of distribution, including the theory of surplusvalue, is thoroughly presented in the works of Marx (1934). In the works of representatives of the neoclassical direction, Marshall, Pi, Clark, Pareto, Engel raised the issues of incomes and their inequality, making it possible to identify consumer behavior patterns depending on available income and form the fundamental basis of modern science. Based on a research of factors affecting income asymmetry in urban slums in southern Sumatera (Indonesia), Suhel et al. (2021), has been proven that in the aggregate, such variables as education level, age, expected income, and type of work, provide both positive and negative impact on the level of income.

Among European contemporaries who devoted their researches to solving the problems of income inequality, can be singled out the works of scientists from the Institute of Demography and Social Research named after Birds of the National Academy of Sciences of Ukraine, Libanova, Vasiliev, Gerasimenko, Zayats, Klimenko, Boychenko, Vasilchuk, Varnaliy, Vorotin, Geyets, Zhalilo, Luchik, Pyatkina, and others. These works greatly contributed to the research of incomes and living standards of the population in the regional context. The global nature of the issues raised in the article is evidenced by the main provisions of the concept of sustainable development. The concept of sustainable development presupposes a set of measures aimed at meeting current human needs while preserving the environment and resources, without prejudice to the ability of future generations to meet their own needs (Agenda 21, 1992). Seventeen Sustainable Development Goals until 2030 were identified, the first of which is eliminating inequality and poverty in any of its manifestations.

In addition, in 2019, Michael Kremer of Harvard and his followers and colleagues Esther Duflo and Abhijit Banerjee of MIT proposed an experimental approach to poverty alleviation that was highly praised by the global scientific community in the field of economics, as a result of which the authors were awarded the Nobel Prize.

It should be noted that the existing popular and sufficiently tested forecasting methods are largely reduced to financial processes and financial activities. This includes including the two-factor and the five-factor model of Altman, the adapted discriminant model of Lis, the discriminant model of Taffler, the diagnostic model solvency of Conan and Golder, Biver's coefficient, Springate's model, Tereshchenko's discriminant model, Sayfullin's model - Kadykov, Zaitseva, etc.

The existing practice of forecasting the main parameters of the asymmetry of the population's income, as a rule, is limited to determining the priorities for the economic and social development of territories and the development of comprehensive and/or targeted programs aimed at their implementation. At the same time, a wide arsenal of forecasting methods is not used to the full extent, which makes it possible to predict future development not only based on the analysis of data from a retrospective period but also on the identification of external and internal factors of influence, taking into account quantitative and qualitative changes taking place in the territorial community (region, district, city, village, settlement). As a result, there is no inconsistency between the needs of resource provision of plans and programs developed for the future and the respective territories' annual budgetary possibilities. 
Thus, the complexity and versatility of the phenomenon of poverty, on the one hand, and the narrow focus, as well as the scientific disunity of the methodological apparatus of forecasting. On the other hand, it has led to research interest in forecasting the asymmetry of the population's income. Based on this, the purpose of the article is to develop theoretical, methodological, and practical approaches to predicting the asymmetry of the population's income in the context of poverty alleviation.

The research object is to forecast the asymmetry of the population's income. The subject is theoretical, methodological, and practical foundations for predicting the asymmetry of the population's income.

\section{METHODS}

In the research, a systematic approach was implemented. Generally, scientific methods were used: analysis, synthesis, induction, deduction, logical analysis (to generalize the views of domestic and foreign scientists to forecast categories, income asymmetry). Statistical analysis and forecasting were used from a set of special research methods. Data processing was carried out using an office suite of Microsoft Office applications, particularly a spreadsheet Microsoft Excel and a text editor Microsoft Word. The information base of the research was the publications of Ukrainian and foreign scientists, the official statistical information of the State Statistics Committee of Ukraine. The initial information for the forecast was the official statistical data, namely: indicators of incomes of the population of Ukraine in dynamics by types of economic activity and in the regional context over the past 10 years (Tables 1-3 Appendix).

The construction of the forecast of the population's income and the asymmetry determination was carried out based on the generalization of homogeneous phenomena (million UAH and ten years). The average values were used to compare the results obtained, making it possible to generalize the characteristics of mass, qualitatively similar socio-economic phenomena, making it possible to predict the main prospects scientifically reasonably. Information for 2014-2019 is given without considering the temporarily occupied territory of the Autonomous Republic of Crimea, Sevastopol, and part of the temporarily occupied territories in the Donetsk and Luhansk regions.

The presented accountings were carried out in the following interpretations: optimistic, pessimistic, and most probable scenarios. The accuracy of these predictions depends on the validity, completeness, and reliability of the diagnosis. From the point of view of the forecasting period (short-term, long-term, medium-term), the author presents a short-term forecast that covers 5 to 10 years since it is the most accurate and has a high degree of detail in the context of constantly changing impact factors.

\section{RESULTS AND DISCUSSION}

A survey analysis of various points of view regarding the current category of "forecasting" made it possible to establish this concept can be considered in a narrow and broad sense. In a narrow sense, the forecast is from the Greek - $\pi \rho$ ó $\gamma \omega \omega \sigma \eta$ "prevision, prediction".

In our research, the forecast is considered broadly since we are talking about a complex and multifaceted process (incomes and their asymmetry), which is constantly influenced by various factors that change the course of events. In this regard, the article's author calls a forecast a scientifically grounded judgment about the possible 
states of the object (income of the population) in the future and (or) about alternative ways and terms of their implementation.

The general goal of forecasting income asymmetry is to provide the necessary information for developing regions' budgets, plans, programs, strategies, economic, social, and sustainable development. Thus, the determination of prospective wages by type of economic activity, by region, profit and mixed-income, income from property, social benefits, trends of natural and mechanical movement in the future, reproduction of labor resources, etc., create the basis on which the determination is made - the priorities and prospects of socio-economic development of territories.

Previous researches made it possible to establish that the following types of risks have the greatest impact on income asymmetry: economic, political, social, and environmental, which included the Covid-19 pandemic. It has been established that the specifics of determining the direction and strength of the action of each of the listed risks is the subjective nature and versatility of their influence. The existence of a direct relationship between the direction of the impact of risks and the reproduction of the main components of the vital activity of the regions leads to the emergence of negative trends in the course of these processes. So, considering the likelihood of certain risks is becoming an important condition in predicting income asymmetry. To predict the population's income asymmetry, we will construct trend models. Description of trend models of income asymmetry by main indicators: presented in (Tables 1, 2, 3)

Table 1. Trend model of income asymmetry in Ukraine

\begin{tabular}{llc}
\hline \multicolumn{1}{c}{ Indicators } & \multicolumn{1}{c}{ Trend model } & $\mathrm{R}^{2}$ \\
\hline Salary & $\mathrm{y}=137447 \mathrm{x}+137920$ & 0.8455 \\
Profit and mixed income & $\mathrm{y}=54570 \mathrm{x}+51165$ & 0.9116 \\
Property income received & $\mathrm{y}=3341,7 \mathrm{x}+64823$ & 0.5132 \\
Social aids and other current transfers received & $\mathrm{y}=79756 \mathrm{x}+268913$ & 0.8907 \\
including social benefits & $\mathrm{y}=29290 \mathrm{x}+192243$ & 0.8480 \\
social transfers actually & $\mathrm{y}=34756 \mathrm{x}+77335$ & 0.8751 \\
\hline
\end{tabular}

Source: Compiled by the author according to Table 5(Appendix)

Table 1 shows that the main share in the structure of incomes of the population of Ukraine falls on wages (47\%), which tends to grow for the analyzed period, like other indicators. Considering the dynamics of changes in the share of sources of income of the population for the period from 2010 to 2019. It can be argued that there is an increase in the volume of wages in the structure of the population's income by $0.83 \%$ on average per year and, conversely, the share of social assistance and other received current transfers decreases by $0.78 \%$ on average per year. In addition, during the analyzed period in 2014, in all indicators, there was a drop in income and an increase in social aids, except for income from the property. This situation is associated with the military conflict in the Donbass, which contributed to the resettlement of 1 million 459 thousand 089 people, reducing income and devastating the savings of the population. (Ministry of Social Policy, 2021). Considering the values of the approximation, it is fair to consider the trend model reliable since for almost all indicators, the average value of $\mathrm{R}^{2}$ was $0.8 \rightarrow 1$. However, in terms of property income, the received $\mathrm{R}^{2}$ was 0.5132 , which indicates that the model does not consider significant factors other than time $\mathrm{t}$. This aspect was considered in the forecast presented in Table 2. 
Table 2. Trend model of income asymmetry of the population of Ukraine by type of economic activity

\begin{tabular}{llc}
\hline Indicators & \multicolumn{1}{c}{ Trend model } & $\mathrm{R}^{2}$ \\
\hline Agriculture, forestry and fisheries & $\mathrm{y}=803.38 \mathrm{x}-390.47$ & 0.8805 \\
Industry & $\mathrm{y}=947.95 \mathrm{x}+435$ & 0.8646 \\
Constructing & $\mathrm{y}=805.21 \mathrm{x}-44.667$ & 0.8768 \\
Wholesale and retail trade; repair of motor vehicles & $\mathrm{y}=993.81 \mathrm{x}-295.73$ & 0.9171 \\
Transport, warehousing, postal and courier activities & $\mathrm{y}=956.72 \mathrm{x}+359.47$ & 0.8587 \\
Temporary accommodation and catering & $\mathrm{y}=576.48 \mathrm{x}+197.47$ & 0.8855 \\
Information and telecommunications & $\mathrm{y}=1569.6 \mathrm{x}-494.27$ & 0.9036 \\
Financial and insurance activities & $\mathrm{y}=1537.2 \mathrm{x}+1176.4$ & 0.8902 \\
Real estate operations & $\mathrm{y}=736.17 \mathrm{x}+206.13$ & 0.9086 \\
Professional, scientific activity & $\mathrm{y}=1252.1 \mathrm{x}+306.73$ & 0.9270 \\
Activities in the field of administrative & $\mathrm{y}=714.22 \mathrm{x}+89.467$ & 0.8348 \\
and support services & $\mathrm{y}=1292.7 \mathrm{x}-722$ & 0.8073 \\
Public administration and defense & $\mathrm{y}=372.93 \mathrm{x}+288.2$ & 0.8470 \\
Compulsory social insurance & $\mathrm{y}=572.38 \mathrm{x}+301$ & 0.8686 \\
Education & $\mathrm{y}=734.24 \mathrm{x}+555.8$ & 0.9337 \\
Health service & $\mathrm{y}=815.33 \mathrm{x}-37.133$ & 0.8996 \\
Art, sport, entertainment and rest & $\mathrm{y}=877.61 \mathrm{x}+221.87$ & 0.8742 \\
\hline Source: Compiled by
\end{tabular}

Source: Compiled by the author according to Table 6 (Appendix)

The result of trend analysis for the indicator "wages by type of economic activity for the period 2010 - 2019, UAH million." is presented in Table 2. It indicates a significant differentiation in the sectors of the economy in terms of the average wages level.

So, unlike European countries, where the highest remuneration for their work is received by qualified workers in the field of high technologies, in science, medicine, education, in Ukraine, this contingent of workers was in the group of low-paid $(<10497$ UAH). The difference between the highest-paid industry, "Financial and insurance activities" (19132 UAH), and the least paid "Temporary accommodation and catering" (6730 UAH) are almost three times in $12402 \mathrm{UAH}$. (65\%). The approximation coefficient for all types of economic activity ranges from 08 to 09 , indicating the forecast's reliability.

It can also be argued that the revenue is expected for such activities as agriculture, forestry, and fisheries; construction; wholesale and retail trade; repair of motor vehicles; information and telecommunications; public administration and defense; arts, sports, entertainment, and recreation to decline by 2020. This forecast coincides with the data of the analytical note of Rozumkov Center. The World Bank predicted it; the poverty rate in Ukraine increased from $2.1 \%$ in 2019 to $2.3 \%$ by the end of 2020 . Although the government in the framework of the macroeconomic forecast for 2020-2022. It was planned to increase the average salary by UAH 2000. Per year, however, the introduction of quarantine caused the growth of the real incomes of Ukrainians to stop. At the end of the first half of 2020, the real disposable income of citizens decreased by $7.3 \%$ compared to the same period in 2019. This was the first drop in real incomes since 2016 (Razumkov Center, 2021). 
Table 3. Trend model of income asymmetry by regions of Ukraine

\begin{tabular}{llc}
\hline Regions & \multicolumn{1}{c}{ Trend model } & $\mathrm{R}^{2}$ \\
\hline Vinnitsa & $\mathrm{y}=10467 \mathrm{x}+10573$ & 0.8983 \\
Volynsk & $\mathrm{y}=5764 \mathrm{x}+6938.9$ & 0.898 \\
Dnipropetrovsk & $\mathrm{y}=28738 \mathrm{x}+25935$ & 0.8918 \\
Donetsk & $\mathrm{y}=45431 \mathrm{x}+122170$ & 0.2526 \\
Zhytomyr & $\mathrm{y}=7687.6 \mathrm{x}+9024.1$ & 0.887 \\
Zakarpattia & $\mathrm{y}=6207.9 \mathrm{x}+7623.3$ & 0.8956 \\
Zaporizhzhya & $\mathrm{y}=13414 \mathrm{x}+16869$ & 0.9079 \\
Ivano-Frankivsk & $\mathrm{y}=7851.1 \mathrm{x}+10032$ & 0.8977 \\
Kiev & $\mathrm{y}=13970 \mathrm{x}+11008$ & 0.879 \\
Kirovograd & $\mathrm{y}=5656.4 \mathrm{x}+8373$ & 0.9037 \\
Luhansk & $\mathrm{y}=331.98 \mathrm{x}+58279$ & 0.0101 \\
Lviv & $\mathrm{y}=17414 \mathrm{x}+16073$ & 0.8842 \\
Nikolayev & $\mathrm{y}=7205.3 \mathrm{x}+10328$ & 0.8921 \\
Odessa & $\mathrm{y}=18410 \mathrm{x}+12366$ & 0.8916 \\
Poltava & $\mathrm{y}=10360 \mathrm{x}+11534$ & 0.8933 \\
Rovensk & $\mathrm{y}=6602.2 \mathrm{x}+8578.1$ & 0.9082 \\
Sumy & $\mathrm{y}=7176.4 \mathrm{x}+9352.1$ & 0.9068 \\
Ternopil & $\mathrm{y}=5397.7 \mathrm{x}+8110.4$ & 0.8978 \\
Kharkiv & $\mathrm{y}=19233 \mathrm{x}+25278$ & 0.8898 \\
Kherson & $\mathrm{y}=6115.9 \mathrm{x}+7964.5$ & 0.9095 \\
Khmelnitsky & $\mathrm{y}=7790.6 \mathrm{x}+10484$ & 0.9096 \\
Cherkasy & $\mathrm{y}=7357.1 \mathrm{x}+9949.2$ & 0.8981 \\
Chernivtsi & $\mathrm{y}=4624.1 \mathrm{x}+6448.1$ & 0.9024 \\
Chernihiv & $\mathrm{y}=5934.6 \mathrm{x}+10390$ & 0.9022 \\
\hline Source: Compied & &
\end{tabular}

Source: Compiled by the author according to Table 7 (Appendix)

The trend analysis of the incomes of the population in the regions of Ukraine made it possible to establish that there is also a significant asymmetry between them over ten years. High incomes are typical for the Dnepropetrovsk industrial region (UAH 89042), Kiev (UAH 76,232), Zaporizhzhya (UAH 76062), Odessa (UAH 75288) and Poltava (UAH 72843) regions. The listed territories' average per capita monetary income per month is almost three times higher than the average Ukrainian one (from UAH 48 to 70 thousand), $151.2 \%$. Forecast data for 2020 indicate that the long-term trend will continue across the regions. The approximation rate for all regions, except for Donetsk and Lugansk, is 0.8-0.9. It indicates the reliability of the forecast.

Regarding the Donetsk and Luhansk regions, it must be said that this dynamics is explained by the military conflict (risk factor) that occurred in 2014, which was not taken into account in the forecast, which indicates an urgent need to study causal relationships. In addition, it should be noted that Covid-19 also made certain adjustments to the structure of trade and economy, and social policy in Ukraine and in all world states. Today, this risk factor is decisive since quarantine exposes the weaknesses of the population's health and socio-economic ones. In this connection, the author proposes to build a medium-term forecast for the main indicators of the asymmetry of incomes of the population of Ukraine until 2024. Table 4 presents the results of forecasting income asymmetry, which was carried out based on the obtained trend models, taking into account the speed of action, the strength of the impact, and the direction of influence of political, social, and economic risks. 
Table 4. The results of forecasting the income asymmetry of the population of Ukraine until 2024

\begin{tabular}{lccc}
\hline Indicators & The year 2024 & $\begin{array}{c}\text { Deflection 2019/2024 } \\
\text { Total } \\
\text { thousand UAH }\end{array}$ & Comparative \% \\
\hline Most possible script & & & \\
\hline Salary, thousand UAH & 2950020.292 & 1191432 & 67.71 \\
Profit and mixed-income & 1205066.592 & 526849 & 77.68 \\
Property income received & 133711.6061 & 16708 & 14.28 \\
Social aids and other current transfers received & 1985178.151 & 794926 & 66.77 \\
including: social aids & 1026341.373 & 467804 & 83.75 \\
social transfers actually & 616228.3819 & 177513 & 40.46 \\
\hline Pessimistic script & & & 10 \\
\hline Salary, thousand UAH & 1932936.50 & 174348 & 10 \\
Profit and mixed-income & 895091.55 & 216874 & 31.98 \\
Property income received & 97820.70 & -19183 & -16.39 \\
Social aids and other current transfers received & 1331101.95 & 140849 & 11.83 \\
including: social aids & 663608.16 & 105071 & 18.81 \\
social transfers actually & 475961.02 & 37246 & 8.5 \\
\hline Optimistic script & & & 126 \\
\hline Salary, thousand UAH & 3967104.08 & 2208516 & 123.38 \\
Profit and mixed-income & 1515041.64 & 836824 & 44.95 \\
Property income received & 169602.51 & 52599 & 121.74 \\
Social aids and other current transfers received & 2639254.35 & 1449002 & 148.7 \\
including: social aids & 1389074.59 & 830537 & 72.43 \\
social transfers actually & 756495.74 & 317780 & \\
\hline
\end{tabular}

So, it follows from the presented forecast that the current trend of the income distribution will continue in the next five years. In addition, it was found that such an indicator requires additional research as "property income received", and the Luhansk and Donetsk regions. Since these regions and this indicator were influenced by risk factors that were not considered in official statistics, which negatively affected the coefficient of reliability $\mathrm{R}^{2}$.

\section{CONCLUSIONS AND RECOMMENDATIONS}

\section{Conclusions}

A survey analysis of scientific points of view regarding the current category of "forecasting" made it possible to conclude that it is advisable to understand as such a scientifically grounded judgment about the possible states of the object (income of the population) in the future and (or) about alternative ways and timing of their implementation. Previous research made it possible to establish that such risks most influence the asymmetry of incomes of the population of the regions of Ukraine as the economic, political, social, and spontaneous short-term risk of Covid-19, the consequences of which are the author's prospective studies. It was found that during the analyzed period of 2010-2019. in Ukraine, a stable trend of income distribution has formed, namely, an asymmetric distribution, which is expressed in a change in the structural income of the population by individual indicators, by types of economic activity and regions, while being in direct dependence on the economic and social development of society.

Trend analysis for the period from 2010 to 2019 gives grounds to assert that the main share in the structure of incomes of the population of Ukraine falls on wages (47\%) and social assistance. The main average per capita income in Ukraine in 2019 was from UAH 48 to 70 thousand. While the regions were identified, the average per 
capita monetary income per month exceeds almost three times the average Ukrainian one. These regions include Dnipropetrovsk, Kiev, Zaporizhzhia, Odessa and Poltava. It was determined that the dominant factor in the growth of income differentiation of the population of Ukraine is the intersectoral gap in the wages of full-time employees. So the difference between the highest-paid industry "Financial and insurance activities" (19132 UAH) and the least paid "Temporary accommodation and catering" (6730 UAH) are calculated as three times - 12402 UAH. (65\%).

In addition, it was found that revenue is expected for such activities as agriculture, forestry, fisheries; construction; wholesale and retail trade; repair of vehicles; information and telecommunications, public administration and defense, arts, sports, entertainment, and leisure to decline in 2020. The presented forecast until 2024 indicates that the current trend will continue in the next five years. It was also found that such an indicator requires additional research as "property income received", and Lugansk and Donetsk regions since these regions and this indicator were influenced by risk factors that were not considered in official statistics, which negatively affected the approximation rate.

\section{Recommendations}

The forecasting results and the author's toolkit for implementing the forecast and assessment of risk factors, developed and published in another article, are offered to local and state authorities. The forecast proposed in the article should become the basis for strategies and programs for the socio-economic development of the regions of Ukraine.

\section{REFERENCES}

"Agenda for the XXI century". (1992). https://documents-ddsny.un.org/doc/ UNDOC / GEN / N92 / 836/55 / PDF / N9283655.pdf.

Analytical overview. (2021). Ukraine 2020-2021: inflated expectations, unexpected challenges. Rozumkov center.

Boychenko, E.B. (2015). Reproduction of productive forces in the context of the development of regional society: questions of theory, practice, diagnosis: a monograph. High Tech Press.

Boichenko, E.B. \& Vasilchuk, N.O. (2018). The Socio-demographic problems of the development of united territorial communities of the Eastern regions of Ukraine. Journal of Perspectives on Financing and Regional Development, 6 (1), 113-124.

Malthus, T. (1836). Principles of Political Economy Considered with a View to their Applications. William Pickering.

Marx, K. (1934). Capital. Criticism of political economy. Party member of the Central Committee of the CP (b) U.

McCulloch, R. (1852). The works of David Ricardo: with a notice of the life and writings. John Murray.

Mill, J. (1993). On Freedom. Science and life, 12(1), 21-26.

Ministry of Social Policy of Ukraine. (2021). https://www.msp.gov.ua/

Quesnay, F. (1960). Selected economic works. Sotsekgiz.

Schumpeter, J. (2004). History of Economic Analysis. School of Economics.

Smith, A. (2016). Research on the nature and causes of the wealth of nations. Eksmo.

Statistical collection "Incomes and expenditures of the population". (2021). State Statistics Service of Ukraine.

Suhel Suhel; Imam Asngari; Mardalena; Ariodillah Hidayat;Abdul Bashir. (2021). Identifying factors influencing the low-income community in urban slum 
settlements in South Sumatera, Indonesia. Jurnal Perspektif Pembiayaan dan Pembangunan Daerah, 9(1), 2355-8520.

Zablodskaya, I.V, Popova, I.V, Vasilchuk, N.O. \& Thor, O.S. (2012). Segmentation of the regional labor market. Knowledge. article distributed under the terms and conditions of the Creative Commons Attribution (CC BY) license (http://creativecommons.org/licenses/by/4.0/). 


\section{APPENDIX}

Table 5. Dynamics of incomes of the population of Ukraine for the period 2010 - 2019, UAH million

\begin{tabular}{|c|c|c|c|c|c|c|c|c|c|c|}
\hline \multirow{2}{*}{ Index } & \multicolumn{10}{|c|}{ Period } \\
\hline & 2010 & 2011 & 2012 & 2013 & 2014 & 2015 & 2016 & 2017 & 2018 & 2019 \\
\hline Total income & 1101175 & 1266753 & 1457864 & 1548733 & 1516768 & 1772016 & 2051331 & 2652082 & 3248730 & 3744060 \\
\hline Wage & 449553 & 529133 & 609394 & 630734 & 615022 & 709590 & 898326 & 1209097 & 1529367 & 1758588 \\
\hline Profit and mixed income & 160025 & 200230 & 224920 & 243668 & 254307 & 323506 & 378213 & 477854 & 572065 & 678217 \\
\hline Property income received & 67856 & 68004 & 80769 & 87952 & 85114 & 80035 & 75452 & 78673 & 91164 & 117003 \\
\hline Social benefits and other current transfers received & 423741 & 469386 & 542781 & 586379 & 562325 & 658885 & 699340 & 886458 & 1056134 & 1190252 \\
\hline including: social help and & 237213 & 263633 & 301621 & 323123 & 311360 & 342562 & 337773 & 391776 & 465776 & 558537 \\
\hline social transfers & 152131 & 164775 & 192827 & 204840 & 195881 & 236647 & 270560 & 382345 & 446193 & 438715 \\
\hline
\end{tabular}

Source: Compiled by the author based on data (Statistical collection "Income and Expenditures of the Population", 2021)

Table 6. Dynamics of average monthly wages by type of economic activity for the period $2010-2019$, million. UAH

\begin{tabular}{|c|c|c|c|c|c|c|c|c|c|c|}
\hline \multirow{2}{*}{ Economic type Activities } & \multicolumn{10}{|c|}{ Period } \\
\hline & 2010 & 2011 & 2012 & 2013 & 2014 & 2015 & 2016 & 2017 & 2018 & 2019 \\
\hline Agriculture, forestry and fisheries & 1472 & 1853 & 2086 & 2340 & 2556 & 3309 & 4195 & 6057 & 7557 & 8856 \\
\hline Industry & 2570 & 3170 & 3478 & 3763 & 3763 & 4789 & 5902 & 7631 & 9633 & 11788 \\
\hline Constructing & 1758 & 2270 & 2516 & 2702 & 2860 & 3551 & 4731 & 6251 & 7845 & 9356 \\
\hline Wholesale and retail trade; repair of motor vehicles & 1877 & 2342 & 2704 & 3010 & 3439 & 4692 & 5808 & 7631 & 9404 & 10795 \\
\hline Transport, warehousing, postal and courier activities & 2658 & 3072 & 3412 & 3589 & 3768 & 4653 & 5810 & 7688 & 9860 & 11704 \\
\hline Temporary accommodation and catering & 1455 & 1777 & 2055 & 2249 & 2261 & 2786 & 3505 & 4988 & 5875 & 6730 \\
\hline Information and telecommunications & 3161 & 3683 & 4286 & 4599 & 5176 & 7111 & 9530 & 12018 & 14276 & 17543 \\
\hline Financial and insurance activities & 4638 & 5377 & 6012 & 6275 & 7020 & 8603 & 10227 & 12865 & 16161 & 19132 \\
\hline Real estate operations & 1856 & 2181 & 2356 & 2757 & 3090 & 3659 & 4804 & 5947 & 7329 & 8626 \\
\hline Professional, scientific activity & 2869 & 3529 & 4252 & 4465 & 5290 & 6736 & 8060 & 10039 & 12144 & 14550 \\
\hline Activities in the field of administrative & 1839 & 2165 & 2430 & 2527 & 2601 & 3114 & 3995 & 5578 & 7228 & 8700 \\
\hline and support services & 2722 & 3036 & 3415 & 3702 & 3817 & 4381 & 5953 & 9372 & 12698 & 14785 \\
\hline Public administration and defense & 1905 & 2079 & 2530 & 2700 & 2745 & 3132 & 3769 & 5857 & 7041 & 8135 \\
\hline Compulsory social insurance & 1628 & 1774 & 2202 & 2367 & 2441 & 2829 & 3400 & 4977 & 5853 & 7020 \\
\hline Education & 1928 & 2358 & 2886 & 3286 & 3626 & 4134 & 4844 & 6608 & 7612 & 8659 \\
\hline Health service & 1717 & 2056 & 2618 & 2707 & 3361 & 3634 & 4615 & 6536 & 8132 & 9096 \\
\hline Art, sport, entertainment and rest & 2239 & 2633 & 3026 & 3265 & 3480 & 4195 & 5183 & 7104 & 8865 & 10497 \\
\hline
\end{tabular}

Source: compiled by the author based on data (Statistical collection "Income and Expenditures of the Population", 2021) 
Table 7. Dynamics of incomes of the population by regions of Ukraine for the period 2010 - 2019, UAH million

\begin{tabular}{|c|c|c|c|c|c|c|c|c|c|c|}
\hline \multirow[b]{3}{*}{ Ukraine } & \multicolumn{10}{|c|}{ Income for the period } \\
\hline & 2010 & 2011 & 2012 & 2013 & 2014 & 2015 & 2016 & 2017 & 2018 & 2019 \\
\hline & 1101175 & 1266753 & 1457864 & 1548733 & 1516768 & 1772016 & 2051331 & 2652082 & 3248730 & 3744060 \\
\hline ARC & 39393 & 45562 & 51759 & 57324 & - & - & - & - & - & - \\
\hline Vinnitsa & 33602 & 38990 & 44265 & 46157 & 49418 & 60923 & 71888 & 94417 & 114480 & 129061 \\
\hline Volynsk & 19137 & 22584 & 25741 & 26907 & 27986 & 34064 & 40792 & 53204 & 63810 & 72185 \\
\hline Dnipropetrovsk & 88922 & 101868 & 118823 & 124594 & 136810 & 166076 & 188816 & 245778 & 307844 & 360385 \\
\hline Donetsk & 118223 & 135599 & 158003 & 166366 & 142745 & 117471 & 117735 & 141340 & 174771 & 199322 \\
\hline Zhytomyr & 26124 & 30069 & 34110 & 34947 & 36814 & 45053 & 53684 & 70126 & 84830 & 97301 \\
\hline Zakarpattia & 20841 & 24446 & 28028 & 29102 & 29988 & 37182 & 44137 & 56568 & 69194 & 78182 \\
\hline Zaporizhzhya & 45779 & 52272 & 59191 & 62671 & 68327 & 81737 & 96695 & 122759 & 147627 & 169384 \\
\hline Ivano-Frankivsk & 26504 & 31224 & 36186 & 37310 & 37848 & 47152 & 56418 & 73474 & 87479 & 98587 \\
\hline Kiev & 42732 & 48990 & 55941 & 58894 & 63342 & 76150 & 90505 & 117755 & 150606 & 173511 \\
\hline Kirovograd & 20213 & 23443 & 27129 & 27695 & 28901 & 35350 & 41875 & 54514 & 63999 & 71713 \\
\hline Luhansk & 51338 & 58619 & 67025 & 71485 & 56233 & 44157 & 41267 & 49342 & 58880 & 66287 \\
\hline Lviv & 54838 & 63602 & 72828 & 75762 & 79378 & 97740 & 116285 & 152256 & 189077 & 216876 \\
\hline Nikolaev & 26034 & 29800 & 33907 & 35125 & 36373 & 44275 & 52390 & 67558 & 81581 & 92529 \\
\hline Odessa & 52924 & 61435 & 70429 & 78285 & 80438 & 101179 & 118472 & 153640 & 193923 & 225458 \\
\hline Poltava & 34462 & 39299 & 44835 & 46984 & 49928 & 60610 & 71926 & 92768 & 114656 & 129647 \\
\hline Rovensk & 22362 & 26144 & 29557 & 31811 & 33314 & 40309 & 47356 & 61831 & 73661 & 82555 \\
\hline Sumy & 24918 & 28347 & 32415 & 33469 & 35375 & 44311 & 52551 & 67287 & 79848 & 89702 \\
\hline Ternopil & 19587 & 22712 & 26102 & 26345 & 26892 & 33851 & 40277 & 52196 & 61731 & 68282 \\
\hline Kharkiv & 67102 & 77316 & 88352 & 91333 & 95897 & 116880 & 135675 & 175850 & 216227 & 245934 \\
\hline Kherson & 20978 & 24096 & 27221 & 29489 & 30077 & 38233 & 44268 & 57144 & 68064 & 76449 \\
\hline Khmelnitsky & 26987 & 31336 & 35458 & 36770 & 38853 & 48653 & 57367 & 73520 & 86821 & 97560 \\
\hline Cherkasy & 26194 & 29646 & 33484 & 35024 & 36694 & 44708 & 53496 & 69399 & 82600 & 92887 \\
\hline Chernivtsi & 16114 & 18682 & 21012 & 22408 & 22941 & 28316 & 33657 & 43542 & 52108 & 58028 \\
\hline Chernihiv & 23179 & 26277 & 29654 & 30393 & 31998 & 38780 & 45716 & 58255 & 69247 & 76808 \\
\hline Kiev & 143903 & 164057 & 194436 & 218747 & 240198 & 288856 & 338083 & 447559 & 555666 & 675427 \\
\hline Sevastopol & 8785 & 10338 & 11973 & 13336 & - & - & - & - & - & - \\
\hline
\end{tabular}

